\title{
MINIMUM WEIGHT DESIGN OF COMPOSITE FLOORS UNDER HUMAN INDUCED VIBRATIONS
}

\begin{abstract}
The paper is concerned with a minimum weight design of composite floors subjected to dynamic loading, deriving from the rhythmic activity of a group of people. The floor structure consists of concrete slab cast, on thick trapezoidal deck, which is supported by a grid of steel beams. The structure is vibration-prone and exhibits a number of natural frequencies, which are within a range of loading function. Mini-mum weight design consists in assigning, from catalogues of prefabricated plates and beams appropriate elements assuring fulfillment of imposed constraints on dis-placements and accelerations. Applied, practical discrete optimization method is based on graph theory and finite element analysis. Efficiency of the proposed de-sign is demonstrated in an example of real-world engineering structure.
\end{abstract}

Keywords: structural optimization, discrete optimization, structural vibrations, composite floor structure

\section{Introduction}

Recent trends in building design exhibit large open spaces, with significant spans between columns, reaching even $9 \mathrm{~m} \mathrm{[6].} \mathrm{On} \mathrm{the} \mathrm{other} \mathrm{hand,} \mathrm{there} \mathrm{are} \mathrm{in-}$ creasing demands for saving of the structural material and fast erection processes. This is reflected in application of new technologies in construction industry. As a result of this, designers have to minimize the structural weight, verifying not only their static behavior, but also assuring required level of serviceability with respect to vibrations. Such a situation was observed on lightweight, London's Millennium Footbridge.

Another example of vibration-prone structure is a composite floor, which consists of a concrete slab cast on a trapezoidal deck, supported by steel beams.

\footnotetext{
${ }^{1}$ Bartlomiej Blachowski, Institute of Fundamental Technological Research, Pawinskiego 5b, 02-106 Warsaw, Poland, bblach@ippt.gov.pl

2 Autor do korespondencji/corresponding author: Witold Gutkowski, Institute of Mechanised Construction and Rock Mining, Racjonalizacji 6/8, 02-673 Warsaw, Poland, wgutkow@ippt.gov.pl
} 
Nowadays, the composite floors are more frequently applied in public and office buildings as well as in hospitals and sport facilities. The above issues were the main reason for new updated recommendations and guidelines for engineers [6], dealing with dynamic problems in structures. Additionally, some standards oblige designers to verify not only the value of natural frequency of the considered structure, but indicate vibration levels, which are acceptable for humans $[4,5]$.

Traditional approach to structural design was an iterative approach, relying mostly on experience of the designer. Currently, design process can be significantly simplified and automated, allowing obtaining a solution by means of optimization procedures. The optimality criteria can be related to the weight of a structure or its cost. Optimization process takes into account several constraints. These constrains are required by structural codes on strength of material, but can be related also to displacement or accelerations.

Among many discrete optimization methods, there are methods, like genetic or evolutionary optimizations. However such methods are time consuming and require a number of parameters, which has to be tuned, in order to obtain an optimal solution. In this paper, an alternative approach has been proposed. It is based on graph representation of the structural optimization problem and is described in detail in previous authors' papers $[2,3]$.

The proposed solution is verified by an example of discrete optimization of composite floor subjected to rhythmic crowd activity.

\section{Vibration response of composite floors}

Dynamic response of a composite floor (Fig.1) is calculated applying Finite Element Method. The vector equations of motion of $N$-degree of freedom system have the following form:

$$
\mathbf{M} \ddot{\mathbf{q}}(t)+\mathbf{C} \dot{\mathbf{q}}(t)+\mathbf{K q}(t)=\mathbf{p}(t)
$$

where

- $\quad \mathbf{M}, \mathbf{C}, \mathbf{K}$ are mass, damping and stiffness matrices respectively

- $\quad \ddot{\mathbf{q}}(t), \dot{\mathbf{q}}(t), \mathbf{q}(t)$ are accelerations, velocities and displacements vectors respectively

- $\mathbf{p}(t)$ is external force vector

The stiffness matrix contains orthotropic properties of the slab, together with offset between mid-plane of the slab and principal axis of the steel beams. 
Applying modal transformation the structural displacement vector $\mathbf{q}(t)$ can be transformed into

$$
\mathbf{q}(t)=\boldsymbol{\Phi} \mathbf{\eta}(t)
$$

where $\boldsymbol{\Phi}$ is matrix whose columns represent mode shapes of the system. First mode shape for typical composite floor is presented on Fig.2.

Substituting (2) in (1) we get

$$
\ddot{\boldsymbol{\eta}}(t)+2 \mathbf{Z} \boldsymbol{\Omega} \dot{\boldsymbol{\eta}}(t)+\mathbf{\Omega}^{2} \boldsymbol{\eta}(t)=\boldsymbol{\Phi}^{T} \mathbf{p}(t)
$$

where

- $\quad \mathbf{Z}$ is modal damping matrix

- $\boldsymbol{\Omega}^{2}=\boldsymbol{\Phi}^{T} \mathbf{K} \boldsymbol{\Phi}$ is the matrix with squares of natural frequencies on its diagonal.
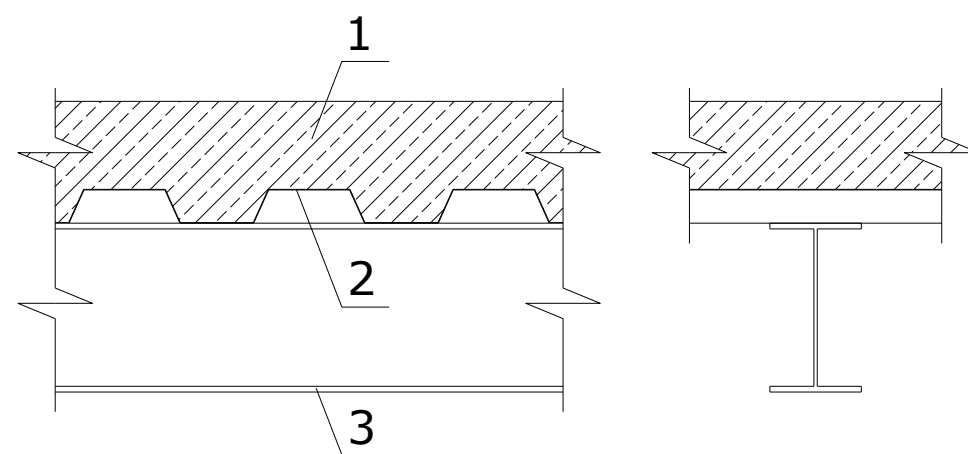

Fig. 1. Steel-concrete composite floor (1-RC slab, 2-trapezoidal steel sheet, 3-steel beam) Rys. 1. Zespolony strop stalowo-betonowy (1-strop żelbetowy, 2-blacha trapezowa, 3belka stalowa

Right hand side of the equation (1) represents time varying load, coming from synchronized human activity. This load can be expanded into Fourier series as follows [6]

$$
\mathbf{p}(t)=\mathbf{B}\left\{1+\sum_{h=1}^{H} \alpha_{h} \sin \left(2 h \pi f_{p} t+\theta_{h}\right\}\right.
$$


where

- $\quad$ B is load pattern vector with components equal to the human weight.

- $\quad H$ is the number of harmonics considered

- $f_{p}$ is frequency corresponding to the first harmonic

- $\quad \alpha_{h}$ is the $h$-th Fourier coefficient

- $\quad \theta_{h}$ is the $h$-th phase lag

Fourier coefficient in the above equation are determined experimentally [1].

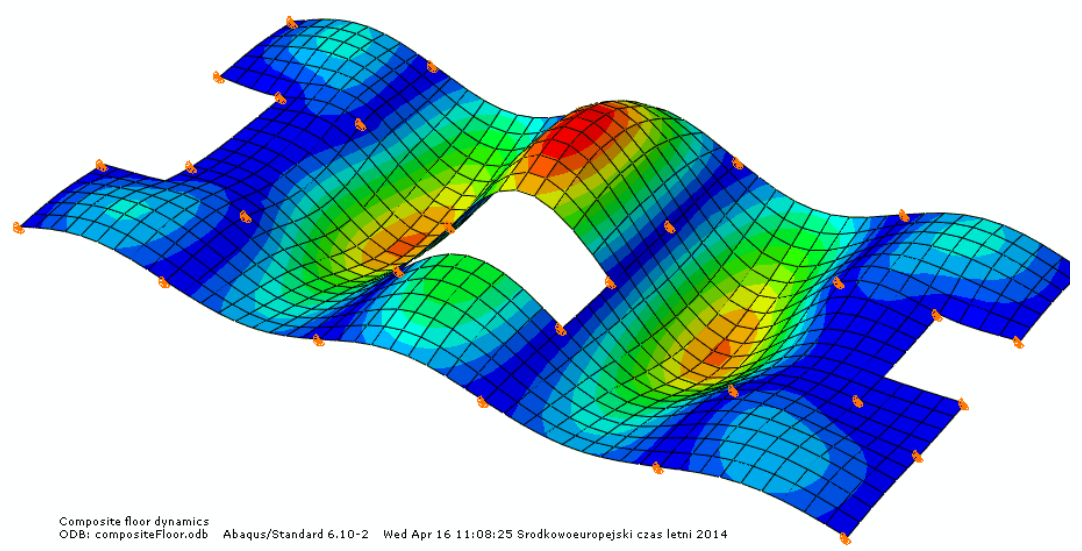

Fig. 2. 1st mode shape of steel-concrete composite floor

Rys. 2. Pierwsza postać drgań stalowo-betonowego stropu zespolonego

Having system matrices and loading vector one can determine vibration response of the composite floor in one of two following ways. In the first approach numerical integration of equation of motion is conducted using one of wellestablished methods (for example Newmark method). Then, having time history of acceleration one can determine root-mean-square (RMS) of acceleration at a given period of time. Example of loading function time history and corresponding acceleration of selected point of composite floor and presented in Fig.3.

The second approach, which is much more computationally efficient, assumes that RMS value of acceleration can be estimated from summation of indi- 

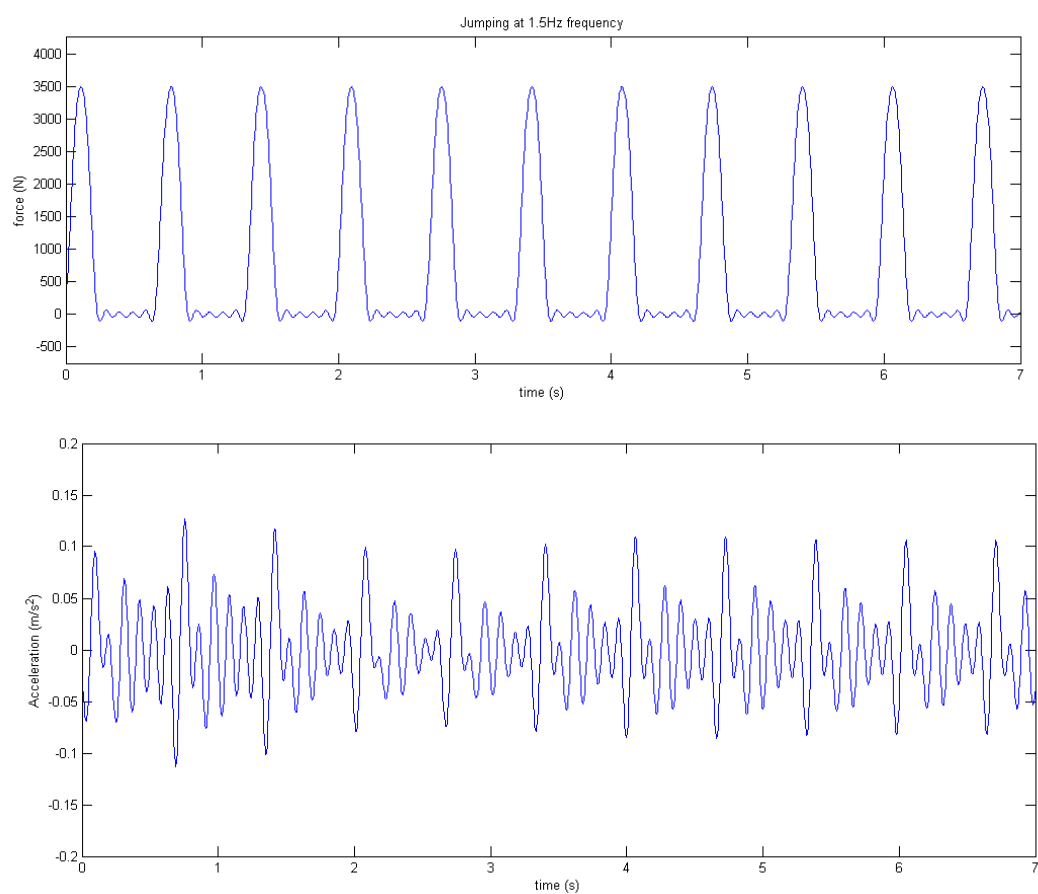

Fig. 3. Time history of loading function (above) and corresponding acceleration of composite floor (below)

Rys. 3. Przebiegi czasowe funkcji wymuszającej (powyżej) oraz odpowiadającej jej wartości przyspieszenia stropu (poniżej)

vidual harmonics for individual mode shapes. This approach can be expressed in the following form

$$
\ddot{q}_{j, h}^{R M S}=\phi_{r}^{(j)} \phi_{e}^{(j)} \frac{\alpha_{h} G}{\sqrt{2}} D_{h}^{(j)}
$$

where

- $\phi_{r}^{(j)}$ is $r$-th component of $j$-th mode shape component corresponding to the point at which response is evaluated

- $\quad \phi_{e}^{(j)}$ is $e$-th component of $j$-th mode shape corresponding to the point at which excitation is applied

- $\quad G$ is weight of the human body (kg) 


$$
D_{h}^{(j)}=\frac{\left(f_{p} / f^{(j)^{2}}-\right.}{\sqrt{\left.\left(-\left(h f_{p} / f^{(j)}\right)^{2}\right)^{2}+h \zeta f_{p} / f^{(j)}\right)^{2}}} \text { is dynamic amplifica- }
$$

tion factor

The RMS of acceleration can be found from summation

$$
\ddot{q}^{R M S}=\sum_{j=1}^{N \operatorname{modes}} \sum_{h=1}^{H} \ddot{q}_{j, h}^{R M S}
$$

\section{Graph based discrete structural optimization}

The applied here minimizing approach is called discrete optimization method. It consists in searching optimal solution among all combinations arising from number of design variables and number of available prefabricated elements listed in a catalogue. From the mathematical point of view this is a combinatorial problem whose computational complexity can be evaluated with aid of the following formula

$$
\prod_{j=1}^{n} m_{j}
$$

where

- $\quad n$ is a number of design variables

- $\quad m_{j}$ is a number of catalogue values for $j$-th design variable.

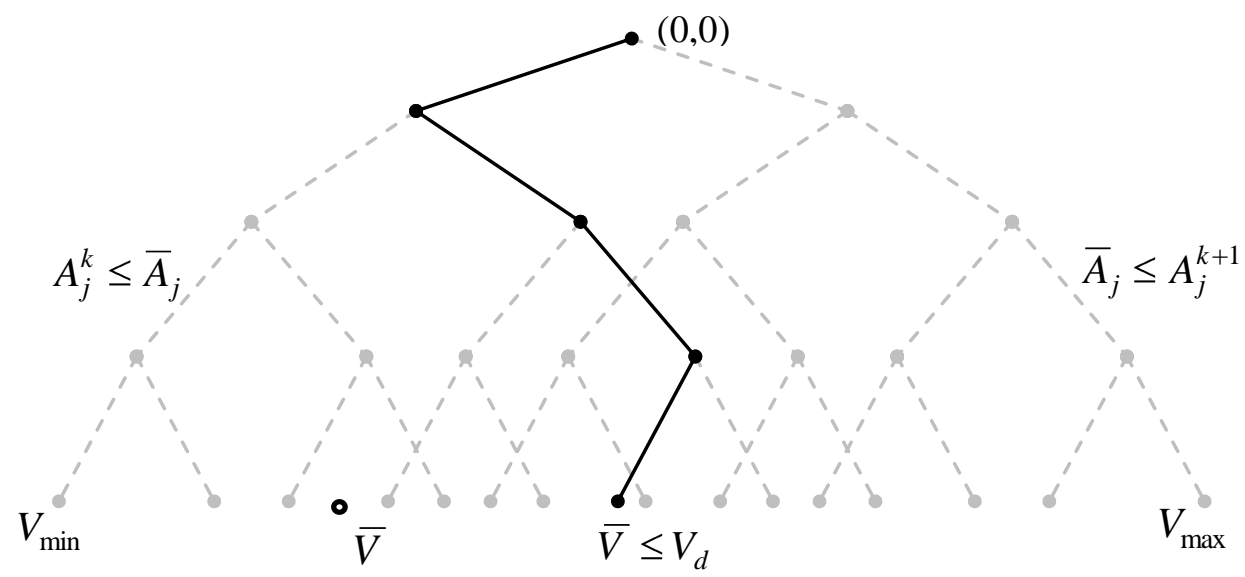

Fig. 4. Graph representation of structural volume

Rys. 4. Objętość konstrukcji reprezentowana przez graf 
From the equation (7), one can easily conclude, that even in a relatively simple problem, which 10 design variables with 10 catalogue available values there are $10^{10}$ combinations. Such a large number of combinations is quite demanding even for modern PC computers. That's why an approximate, heuristic method has to be used. Most common discrete optimization methods are evolutionary algorithms. However, they rely on a numbers of parameters, which have to be found experimentally.

Graph based discrete optimization method is a simpler, alternative for evolutionary algorithms. It relies only on a continuous optimum and graph representation of the cost function. Each of two branches of the tree graph (Fig.4) is created from a set of numbers representing round-down, and round-up values of the continuous solution, as follows:

$$
A_{j}^{k} \leq \bar{A}_{j} \leq A_{j}^{k+1} \quad, j=1,2, \ldots n
$$

where $\bar{A}_{j}$ is $j$-th design variable obtained in continuous optimization process.

Assuming that discrete solution cannot be smaller than continuous one, a large number of combination is removed from further consideration.

$$
\bar{V} \leq V_{d}
$$

Where $V_{d}=\sum_{j=1}^{n} A_{j}^{m_{j}} l_{j}$ is volume of the structure for discrete values of design variables and $l_{j}$ is a length of $j$-th design variable.

Details of the graph based discrete optimization are presented in previous authors' papers $[2,3]$.

\section{Numerical example}

The presented example deals with the discrete optimization of a composite floor subjected to synchronized crowd activity. The floor under consideration is composed of a concrete slab and a grid of supporting beams (Fig.5). The data for the structure are taken from the paper by Smith et al. [6]. The concrete slab is cast on top of $0.9 \mathrm{~mm}$ trapezoidal steel deck. The slab is supported by $9 \mathrm{~m} \mathrm{sec}-$ ondary steel beams, which, in turn, are supported by primary beams. The beams are selected from British Universal Beams Catalogue, containing 55 different sets of I-beams with cross section areas ranging from $16.5 \mathrm{~cm}^{2}$ to $228.1 \mathrm{~cm}^{2}$. The thickness of the RC slab can be selected from 5 different values [0.10; 0.12; $0.14 ; 0.16 ; 0.18 ; 0.20] \mathrm{m}$. Slab thickness together with 5 cross sectional areas of steel beams are taken, as 6 design variables in the problem, which gives 5 times $55^{5}$ possible combinations. 
All mode shapes below $20 \mathrm{~Hz}$ have been found. Modal damping for all modes is $1 \%$ of critical damping. Constraints were imposed on stresses, displacement and accelerations.

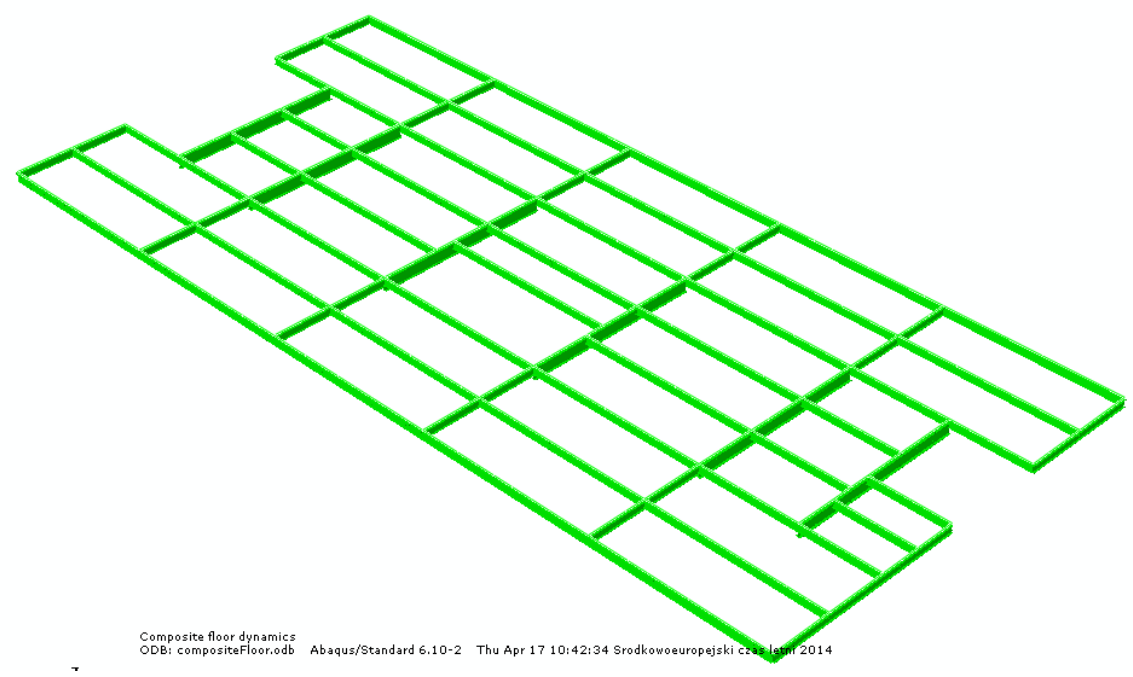

Fig. 5. Grid of steel beams supporting concrete slab

Rys. 5. Ruszt belek stalowych stanowiących podporę dla płyty żelbetowej

According the algorithm presented in paper [3], in order to find minimum weight of the composite floor the following steps have been proceeded:

Step 1. The weight of all 6 structural components (design variables) are obtained from continuous optimization. They are presented in Table 1.

Step 2. The list of two closest catalogue values to continuous ones are also listed in Table 1.

Step 3. Three graphs are created for different order of design variables.

Step 4. Based on the 3 graphs from previous step, 3 different weights of the total structure are found $[252178 ; 252282 ; 291980] \mathrm{kg}$.

Verifying static and dynamic constraints for all three cases, we found that the lowest weight solution doesn't fulfill imposed constrains. Then, the solution with weight equal to $252282 \mathrm{~kg}$ has been selected as the discrete optimal solution. The corresponding cross section areas and slab thickness are presented in Table 1. 
Table 1. Optimal cross section areas of the beams and RC slab thickness

Tabela 1. Optymalne przekroje i grubość płyty żelbetowej

\begin{tabular}{|c|c|c|c|}
\hline $\begin{array}{l}\text { Linking } \\
\text { group }\end{array}$ & $\begin{array}{c}\text { Continuous } \\
\text { solution }\end{array}$ & $\begin{array}{l}\text { Two-branch graph } \\
\text { for beams and plate }\end{array}$ & $\begin{array}{l}\text { Discrete } \\
\text { solution }\end{array}$ \\
\hline $\begin{array}{c}1 \\
\text { (concrete plate) }\end{array}$ & 250.00 & $\{250.00,300.00\}$ & $\begin{array}{c}250.00 \\
(\text { Slab thickness }=\mathbf{1 0} \\
\mathbf{c m})\end{array}$ \\
\hline $\begin{array}{c}2 \\
\text { (9m secondary } \\
\text { beams) }\end{array}$ & 58.88 & $\{56.99,59.82\}$ & $\begin{array}{c}59.82 \\
(\text { UB 457x152x60) }\end{array}$ \\
\hline $\begin{array}{c}3 \\
\text { (9m primary } \\
\text { beams) }\end{array}$ & 164.07 & $\{149.15,179.06\}$ & $\begin{array}{c}179.06 \\
(\text { UB 610x305x179) }\end{array}$ \\
\hline $\begin{array}{c}4 \\
(6 \mathrm{~m} \text { primary } \\
\text { beams })\end{array}$ & 108.33 & $\{101.19,109.04\}$ & $\begin{array}{c}109.04 \\
(\text { UB 533x210x109) }\end{array}$ \\
\hline $\begin{array}{c}5 \\
(9 \mathrm{~m} \text { perimeter } \\
\text { beams })\end{array}$ & 65.94 & $\{60.05,67.12\}$ & $\begin{array}{c}60.05 \\
(\text { UB 533x210x60) }\end{array}$ \\
\hline $\begin{array}{c}\text { Structural } \\
\text { weight }(\mathrm{kg})\end{array}$ & 251780 & $\{249330,295570\}$ & 252282 \\
\hline
\end{tabular}

\section{Conclusions}

Minimum discrete weight of the composite floor, under constraints imposed on displacement and accelerations is found. The considered structure was subjected to dynamic loading induced by rhythmic crowd activity. Discrete optimum is calculated for a set of three different graphs. Solution procedure is relatively simple, comparing with other discrete optimization methods.

\section{References}

[1] Bachmann H. and Amman W.: Vibrations In Structures: Induced by Man and Machines, IABSE, 1987.

[2] Blachowski B., Gutkowski W..: A hybrid continuous-discrete approach to large discrete structural optimization problems, Structural and Multidisciplinary Optimization, vol. 41, Issue 6, 2010, pp.965-977.

[3] Blachowski B., Gutkowski W.: Graph based discrete optimization in structural dynamics, Bulletin of the Polish Academy of Sciences, Technical Sciences, Vol. 62, No. 1, 2014, pp.91-102.

[4] BS 6472:1992 Guide to evaluation of human exposure to vibration In building $(1 \mathrm{~Hz}$ to $80 \mathrm{~Hz}$ ), British Standards Institution, 1992.

[5] ISO 10137 Bases for design of structures - Serviceability of buildings against vibration, International Organisation for Standardization, 2007. 
[6] Smith A.L., Hicks S.J., Devine P.J., Design of floors for vibration: A new approach, Revised Edition, SCI Publication P354, 2009.

\section{DYSKRETNA OPTYMALIZACJA STROPÓW ZESPOLONYCH PODDANYCH DRGANIOM WYWOLANYCH PRZEZ LUDZI}

\section{Streszczenie}

W pracy przedstawiono optymalizację ze względu na minimum ciężaru stropów zespolonych poddanych dynamicznym obciążeniom wywoływanym przez rytmicznie poruszającą się grupe ludzi (np. podczas ćwiczeń). Rozpatrywana konstrukcja stropu składa się z płyty żelbetowej wylewanej na szalunku traconym w postaci blachy trapezowej, która z kolei oparta jest na kształtownikach stalowych. Taka konstrukcja stropu jest podatna na drgania i posiada wiele częstotliwości własnych znajdujących się w zakresie wymuszeń dynamicznych. Proponowana w pracy minimalizacja ciężaru polega na doborze grubości płyty żelbetowej $\mathrm{z}$ określonego zestawu grubości oraz doborze belek stalowych z katalogu profili walcowanych, całość przy spełnieniu nałożonych ograniczeń na naprężenia, przemieszczenia i przyspieszenia. Efektywność metody została zaprezentowana na przykładzie rzeczywistej konstrukcji inżynierskiej tego typu.

Słowa kluczowe: optymalizacja konstrukcji, dyskretna optymalizacja, drgania, stalowo-betonowe stropy zespolone

DOI: $10.7862 / \mathrm{rb} .2014 .25$

Przestano do redakcji: 24.04.2014 r.

Przyjęto do druku: 04.09.2014 r. 